\title{
Analysis of the Online Registration System at Caruban Hospital in 2020
}

\author{
Iin Suwandari ${ }^{1}$, Ratna \\ Wardani \\ ${ }^{1}$ Independent Dentist in Madiun \\ City \\ ${ }^{2}$ Post Bachelor, Faculty of Public \\ Health Sciences Institute of \\ Health Strada Indonesia \\ Email: \\ iinsuwandari@gmail.com
}

Received : January 20 2021

Accepted : May $4^{\text {th }} 2021$

Published : May 20 2021

\begin{abstract}
Backgorund: Information technology can support medical record services in hospitals, especially in patient registration places. The implementation of this technology can be done by applying an online registration system. This system will be able to save waiting time for patients to register

Purpose: This study aims to determine the implementation of the online registration system at Caruban Regional Public Hospital, Madiun District

Method: This study uses a qualitative method with a case study approach. The sampling technique used was purposive sampling with an informant of 6 registration officers and 20 patients.

Result: The online registration system starts in July 2020. The results of the interview show that the system has not been optimally used. Some of the problems are that many patients are elderly so they are not technologically literate, geographic location of the patient cause difficult signals, the patient's electronic devices, and the lack of socialization from registration officer to patients. Patients know only from brochures or banners, so patients do not know the steps to use the system in detail

Conclussion: The online registration system at Caruban Regional public Hospital is not optimal because there are several problems, such as the large number of elderly patients, the reluctance of the community to try to use the system and the lack of socialization.
\end{abstract}

Keywords: Information technology, registration officer, registration system, medical record

Copyright (C) 2021 IIK STRADA Indonesia All right reserved.

This is an open-acces article distributed under the terms of the Creative Commons Attribution-ShareAlike 4.0 International License.

\section{INTRODUCTION}

Hospital is a health service institution that provides complete individual health services that provide inpatient, outpatient and emergency services. Medical Records and Health Information services is one of hospital services (Indonesian Health Ministry, 2010). Referring to Republic Indonesia Ministry of Health Regulation (2008), medical record is files containing notes and documents regarding the patient's identity, examination, medication, actions and other services that have been provided to patients. Today, the development of information technology, cannot be separated in providing medical record services to patients.

Medical record service starts when patient registers at the Registration service. The application of information technology in this unit is very helpful in providing services to patients. Web-based online registration is an implementation that can be used to improve service quality in the registration section (Pratama, 2020). This system has several advantages such as shortening the time to get queue numbers, efficient in time and effective in queuing (Martiana, 2020). 
Caruban Regional Public Hospital is a health service facility that has implemented online patient registration. The online registration system that is implemented was divided into 3 types that are via Short Message Service (SMS), WhatsApp and service packaged. The results of interviews with the medical record officer, there are some problems with the online system registration. This system has ineffectiveness of the online outpatient registration system such as cancellation of registration without confirmation, cancellation of registration with confirmation, increased workload for officers to delete registration history and history of participant eligibility letter which causes inefficient in working time. Based on the description above, this study aims to analyze the implementation of the online registration system at Caruban Regional Public Hospital, Madiun districts.

\section{METHODS}

This research use qualitative methods with case study approach. This method is carried out by examining the condition of the natural object with the data collection technique carried out in a combination, data analysis is inductive, and the results of qualitative research emphasize meaning rather than generalization (Sugiyono, 2013).This research was conducted after getting a certificate of passing the ethical test with a number :1999/KEPK/VI/2020

This research was conducted at the Caruban regional public hospital, Madiun District. The research was conducted in May-June 2020. The population in this study were all patients who came to get treatment at Caruban regional public hospital. Sampling technique used purposive sampling with by criteria patien has age between 25 until 40 years old, directly involved in online registration, and patient has registered online more than 1 time.

The variable in this research is online registration system. The instrument used is a list of questions that will be asked to the sample who acts as an informant. The informants in this study consisted of two type, the first was registration officers and the second is patients who visited Caruban regional public hospital who met the criteria. In collecting data from informants, researchers also applied the principles of research ethics consisting of informed consent, anonymity, and confidentiality.

This analysis is carried out on data obtained from observations, interviews or descriptive observations contained in field notes, which can be seen from the appendix book. Descriptive observation means making comprehensive observations of something in the research setting

1. Taxonomy Analysis

Taxonomic analysis aims to deepen the data that has been found, by asking a number of contrasting questions. The data obtained from selected interviews are included in the field notes contained in the appendix book

2. Analisis Komponen

This analysis aims to look for differences that are specific to each detail generated by the taxonomic analysis

3. Theme Analysis

Theme analysis is a set of procedures to holistically understand the problem being studied.

4. Data Interpretation

Data interpretation is an attempt to obtain a deeper and broader meaning and meaning of the results of the research that is being carried out. Discussion of research results is carried out by critically reviewing the results of research with relevant theories and accurate information obtained from the field.

\section{RESULTS}

The data was carried out by conducting in-depth interviews with informants and patients faceto-face as well as by long-distance telephone conversations. The informants in this research consisted of 6 registration officers and 20 patients by asking several questions. List of questions and answers of informants is presented in Table 1 and Table 2. 
Table 1. Results of interviews with registration officers

\begin{tabular}{|c|c|}
\hline Question & Answered \\
\hline $\begin{array}{l}\text { How is the implementation of } \\
\text { the online registration system at } \\
\text { the Caruban regional public } \\
\text { hospital. In this question the } \\
\text { researcher asked several points } \\
\text { related to the implementation of } \\
\text { the system which consists of: } \\
\text { When did the online registration } \\
\text { system start } \\
\text { Did online registration reduce } \\
\text { queue length at registrations } \\
\text { patient } \\
\text { Problems found in } \\
\text { implementation of online } \\
\text { registration system }\end{array}$ & $\begin{array}{l}\text { 1. The results of the interview show that the online } \\
\text { registration system has been used in July } 2020 \text {. } \\
\text { 2. According to the informant, this system is } \\
\text { actually very helpful in reducing length of queues } \\
\text { in the registration office, but the thera are some } \\
\text { problem such as lack of socialization so that } \\
\text { many patients did not know about this system } \\
\text { clearly, Patients still rarely register online } \\
\text { because many elderly patients. } \\
\text { 3. There are problems with the software, so it is } \\
\text { necessary to develop an Information Technology } \\
\text { system that supports the online registration } \\
\text { system }\end{array}$ \\
\hline $\begin{array}{l}\text { Did all patients understand } \\
\text { about the online registration } \\
\text { system } \\
\text { and able to register online at } \\
\text { home. In this question, } \\
\text { researcher asks whether this } \\
\text { system is very helpful for } \\
\text { patients, and what is the } \\
\text { problems of this system }\end{array}$ & $\begin{array}{l}\text { The results of the interview revealed that there was } \\
\text { a lack of socialization so that many patients } \\
\text { preferred to register manually or use Whatsapp. } \\
\text { Patients who registered online were only } 1-5 \\
\text { patients. The problem from this system are that } \\
\text { many patients are elderly who are not understand } \\
\text { about information techonolgy. Geographic location } \\
\text { causes poor signals, which hinders the use of this } \\
\text { system. }\end{array}$ \\
\hline $\begin{array}{l}\text { Are human resources in the } \\
\text { medical records department } \\
\text { already understand very well } \\
\text { about the online registration } \\
\text { system and } \\
\text { has done the task according to } \\
\text { the standard operating } \\
\text { procedure. In this question also } \\
\text { asked the involvement and role } \\
\text { of the hospital management in } \\
\text { to solve the length of queue in } \\
\text { registration officer }\end{array}$ & $\begin{array}{l}\text { Human Resouces in registration officer has known } \\
\text { and understood about online registration system in } \\
\text { Caruban regional public hospital. This conclusion } \\
\text { obtained from interview with the registration } \\
\text { officer can explain the standard operating } \\
\text { procedure for online registration very well. The } \\
\text { result of interview also obtained there are } 3 \\
\text { informants stated did not about response and } \\
\text { involvement from the hospital management. }\end{array}$ \\
\hline
\end{tabular}

Table 1 explained the executive summary from interview with registration officer or medical record officer that interact with online registration system. First question, ask about the implementation of online registration system in Caruban regional public hospital. Researcher asks some questions consisting of when this system implemented in the hospital, was the online registration system reduce length of queue, and the problems when implemented this system.

The result of interview gave some importants informations. Most of informant stated that the system start at July 2020. Informant also stated that actually this system very helpul for reduce length of queue. But in fact, there are some problems when implemented the system such as lack of socialization which causes patient did not undertand about how to use online registration system.

Thes second question ask whether all patient understood about online system registration at Caruban regional public hospital. Informat given information that many patient prefer choose to manual registration or use whatsapp than online registration system. This condition caused lack of socialization which caused patient did not know about the system. Beside that, many patients are elderly which caused they don't know about information technology. Geograhic location also affect factor to used online registration system because location related to signal quality.

The last question to registration officer is about human resources knowledge. Researcher ask whether they understand and do the job accordingly standard operating procedure. 
Registration officer can explained the standard operating procedure and the flow of online registration system such as "First patients acces hospital website at rsudcaruban.madiunkab.go.id then install online registration application (APEMA). Next step patient fill the registatation form complety".

In an effort to improve quality, 3 informants stated that management always evaluate and development to increase quality services. But, 3 informants other, stated that they don't't know about hospital management response and envolvement to increase quality services especially for reduce length of queue. This condition indicates that coordination it is not yet optimal between management and registration officer.

Table 2. Results of interviews with patients

Question
How is the implementation of the
online registration system at the
Caruban regional public hospital.
In this question the researcher
asked several points related to the
implementation of the system
which consists of:
a. Is the online registration system
help patient to regist.
b. What is the problem when use
online registration system.
c. What is your perception about
online registration sytem in
caruban regional public hospital
d. Weaskness of online
registration system in this
hospital
e. Is the online registration system
at running properly
f. What is your suggestion for
registration system in this
hospital.

Do all patients understand about the online registration system and able to register online
Are human resources in the medical records department already understand very well about the online registration system and has done the task according to the standard operating procedure

\begin{abstract}
Some patien have been understand about online registration system but the prefer use whatsapp. 6 Patient prefer use manual registration.
\end{abstract}

Registration officer friendly and polite but registration officer never explained about that system. Patients only see form banner. For facility and infrastructure, patient wish registration room should be expanded.

The second interview have been done with patients. Total patient that have been interviewed are 20 patients. Form the interview, for the first question there is answer vary. Almost all respondent stated that online registration system very helpful because patient did not need long time for queue. The problem are patient prefer use regist with handphone especially with whatsapp. Many patient are elderly so they did not know about the online registration system. There are Patient did not use online registration system because have not just tried.Patient also stated that their handphone do not support to online registration system and the signal is poor. Hospital management should make socialization so all patients know about this system. Patient has complaint that registration officer response slowly. Actually, online registration system made easy and quick.

Did all patients understand about the online registration system and able to register with online system. Some patients have been understood about online registration system but the prefer regist with whatsapp. Form interview also get information that six patient regist manually.

The last question is whether human resources in the medical records department already understand very well about the online registration system and has done the task according to the standard operating procedure. Registration officer friendly and polite but registration officer never 
explained about that system. Patients only see form banner. For facility and infrastructure, patient wish registration room should be expanded.

\section{DISCUSSION}

The registration officer at the hospital plays an important role because it is the initial gateway for patients to get services at the hospital. The registration officer is a key element in coordinating the activities of other units in the hospital which begins with patient registration. Registration service is a type of front office service that is the spearhead of service because it is the first service and interacts directly with patients, so that it can give patients an impression of the quality of service in general. The results form another researcher, provide information that waiting time has a significant relationship with patient satisfaction. Long waiting time results in decreased patient satisfaction (Laeliyah, 2017).

The use of information technology in patient registration can reduce waiting times in patient registration services. Information technology that can be used is online registration. Research has proven that using online registration can increase satisfaction, profit and save waiting time (Sa'idah, 2017).

Caruban regional public hospital has implemented online registration since July 2020. The results of the interview, this system should be able to reduce length of queues that occurred at the registration section. However, because there are still very few patients who use online registration, this system is not optimal. In implementing this system, several problems were encountered. Demography is an obstacle in implementing online registration at Caruban regional public hospital. Most of the patients who visit are elderly, which causes the patient to not be technologically literate. This result is in line with the research which resulted in the conclusion that one of the obstacles is that patients who are elderly can not use cellphones or are not literate towards technology (Devi, 2019).

Geographic location of patient is another problem to implemented this system. Patients who come from saradan or areas close to Bojonegoro have poor signal. In fact, to access the online registration system, a stable internet connection and a cellphone with a certain OS is required (Marjuni et all, 2017). These results can be used as the basis for hospitals to develop applications so that they can be accessed easily. Online registration applications also need to consider perceived of usefulness. A system that is easy to learn, flexible and easy to use will depend on the intensity of use (Dinata, 2020).

Socialization is also an obstacle in implementing the online registration system. The patient stated that no officer had ever explained about the online registration system at Caruban regional public hospital. Patient know online registration system only form the announcement or banner. This condition clearly has an impact on the patient's lack of understanding of the online registration system because there is no detailed explanation about how to use the online registration system. Management can include socialization programs in registration Standard Operating Procedures. Registration officer must explaine step by step online registration system flow to patient when patien regist in registration office.

The results of interviews with patients also provide information that hospitals should improve facilities and infrastructure need to be improved, especially expanded registration rooms. This condition is caused because there are still many patients who choose manual registration compared to online registration. A large registration room will increase patient satisfaction because when queuing, there are still seats available (Rensiver, 2018).

\section{CONCLUSION}

The online registration system at Caruban regional public Hospital began in July 2020. The results of the interview revealed that the online registration system was still not running optimally. The problem when implemented this system are large number of elderly patients who are not literate in technology, inadequate devices, and the reluctance of the public to try to use the online registration system even though they already know. Socialization is also a factor that causes the application of this online registration system to be not widely used. The majority of respondents know the online registration system from the banners or announcements so that there is no detailed explanation on how to use this online registration system.

\section{ACKNOWLEDGMENTS}

The author is thankful for respondents for their valuable information and its awareness to participate in this research.

\section{CONFLICTS OF INTEREST:}

The author declares that they have no conflict of interest 


\section{REFERENCES}

Devi, F. Z., Dewi, E. R., 2019. Studi Evaluasi Sistem Informasi Pendaftaran di Rumah Sakit Umum Daerah dr. Loekmono Hadi Kudus. Jurnal Kesehatan Masyarakat STIKES Cendekia Utama Kudus. Vo.7. No.1

Dinata, F. H., Nurmawati, I., Muflihatin, I., 2020. Evaluasi Pendaftaran Online dengan Technology Acceptance Model di Rumah Sakit Wongsonegoro Semarang. Jurnal Rekam Medik dan Informasi Kesehatan. Vol.1. No.3

Indonesia Health Ministry. 2008. Indonesian Health Ministry Regulation 129/MENKES/SK/II/2008 about Minimum Hospital Service Standards.

Indonesia Health Ministry. 2010. Indonesian Health Ministry Regulation 129/MENKES/SK/II/2008 about Minimum Hospital Service Standards.

Indonesia Health Ministry. 2010. Indonesian Health Ministry Regulation 340/MENKES/PER/III/2010 about hospital classification.

Laeliyah, N., Subekti, H., 2017. Waktu Tunggu Pelayanan Rawat Jalan dengan Kepuasan Pasien Terhadap Pelayanan di Rawat Jalan RSUD Kabupaten Indramayu. Jurnal Kesehatan Vokasional. Vol.1. No.2

Marjuni, Kurniawan E., Rizal, M. Windarto, H. S., 2017. Aplikasi Pendaftaran Online di RSJD Dr. RM. Soedjarwadi Provinsi Jawa Tengah Berbasis Android. Jurnal STMIK EL RAHMA Yogyakarta

Martiana. 2020. Evaluasi SIMRS Bagian Pendaftaran Online Pasien Rawat Jalan di RSUD Dr. Tjitrowadojo Purworejo. Prosiding:Seminar Nasional Rekam Medis dan Informasi Kesehatan.

Rensiver, Azwar, V. Y., Putra, A. S., 2018. Analisis Faktor Kualitas Pelayanan Terhadap Kepuasan Pasien Rawat Jalan di RSUD DR. Achmad Darwis. Jurnal Kesehatan Andalas. Vol.7 (Supplement 2).

Pratama, T. W. Y., Sudalhar, Abdillaah, F. . 2020. Pengembangan Sistem Informas Pendaftaran dan Pelayanan Pasien Rawat Jalan Berbasis Web di Puskesmas Padangan Kabupaten Bojonegoro. Jurnal Manajemen Informasi Kesehatan Indonesia. Vol.8. No.

Sugiyono. (2017). Metode Penelitian Kuantitatif, Kualitatif dan R\&D. Alfabeta CV. 